\title{
Changes in terms of metabolic syndrome, its occurrence in the civilian population, and in Hungarian and foreign military organizations
}

\author{
PUSZTAI Ágnes ${ }^{1}$, SCHANDL László ${ }^{2}$
}

\begin{abstract}
Obesity again has become the center of attention due to its growing incidence experienced in the last decade and its strong coherence to cardiovascular diseas- es. Especially abdominal obesity together with dyslipidemia featuring hypertonia, hyperglycemia, high level of triglycerides, and low level of $H_{D L}^{3}$ cholesterol ac-counts for cardiovascular risks. The independent and comprehensive term meta-bolic syndrome is used for their frequent collective occurrence and combination. In the past years, the term cardiometabolic risk was created by considering other cardiovascular factors besides the components of the syndrome.

Increase in the number of the obese was observed in military organizations world- wide, too. Parallel to obesity, there is a growing number of both professional and contracted servicemen in the Hungarian Defence Force exposed to the increased danger of cardiometabolic disease according to the metabolic syndrome criteria's. The efficient reduction of cardiometabolic risk is possible with appropriate pre-vention strategies. The population's primary and secondary prevention starts in primary care with the involvement of family doctors, but it is also a fundamental re-sponsibility in the military healthcare system in order to preserve a force fit to fight. Keywords: obesity, metabolic syndrome, cardiovascular and cardiometabolic risk
\end{abstract}

Obesity, especially abdominal obesity is a risk factor relating to cardiovascular diseases and diabetes mellitus type II. It often collocates with high blood pressure, hyperglycemia, and dyslipidemia characterized by an increased level of triglyceride and low level of HDL cholesterol. Their collocation or combination is called metabolic syndrome. (Alberti et al.,

2009) According to the data, including all European countries and recently published by the World Health Organization ${ }^{4}$, death caused by cardiovascular diseases account for more than half of all death, even more than tumors and chronic respiratory illnesses. (WHO, 2009) Hun- garian mortality figures indicate the same, although death caused by chronic liver diseases occurred more than death by chronic respiratory illnesses in 2009 (Table 1.).

1 Medical Doctor, Medical Center, Hungarian Defense Forces - Outpatient Clinic, Budapest, Hungary

2 Medical Doctor, physician brigadier general, PhD Medical Center, Hungarian Defense Forces - Outpatient

Clinic, Budapest, Hungary

3 high-density lipoprotein

4 WHO

PUSZTAI Ágnes, SCHANDL László: Changes in terms of metabolic syndrome, its occurrence...

\begin{tabular}{|l|c|c|}
\hline & $\mathbf{2 0 0 9}$ & $\mathbf{2 0 1 1}$ \\
\hline $\begin{array}{l}\text { Total } \\
\text { Death caused by the most frequent diseases }\end{array}$ & 130414 & 128795 \\
\hline Malignant tumor & 32536 & 32670 \\
\hline Severe necrosis of the heart muscle & 7709 & 7085 \\
\hline Other cardiovascular diseases & 25477 & 26145 \\
\hline Cerebrovascular disease & 14145 & 13369 \\
\hline Chronic respiratory illness & 4734 & 4843 \\
\hline Chronic liver disease & 5080 & 4146 \\
\hline
\end{tabular}

Table 1. Age-standardized mortality rate by main causes of death in 2009 and 2011

based on data of $\mathrm{KSH}^{5}$

IDEA $^{6}$ was a large, international, cross-sectional research, including 63 countries, to an- alyze the data of 168,000 patients of primary care. Based on the results, waist measurements and geographical distribution obesity was evaluated. 
The conclusion was as follows: waist measurement besides BMI figures is a valuable marker for cardiovascular diseases and di- abetes mellitus type II. In the Eastern European region, cardiovascular diseases occurred with outstandingly high frequency both among men (27\%) and women (24\%), unlike in other regions, where these figures were between $8 \%$ (Canadian women) and 16\% (Northern European men). Diabetes mellitus has shown more regional differences than cardiovascular diseases. Other than the East Asian (cardiovascular diseases) and the South Asian (diabetes) region, both diabetes and cardiovascular diseases are experienced more among men than women. The agestandardized occurrence of diabetes mellitus was the highest in the Middle East (men: 22\%, women: 19\%), in Northern Africa (men: 19\%, women: 16\%), and South Asia (men: 17\%, women: 18\%) (Balkau et al., 2007)

5 Central Department of Statistics, http://www.ksh.hu/docs/hun/xstadat/xstadat_eves/i_wnh001.html (downloaded: 2005 2013)

6 Internal Day for the Evaluation of Abdominal Obesity

PUSZTAI Ágnes, SCHANDL László: Changes in terms of metabolic syndrome, its occurrence...
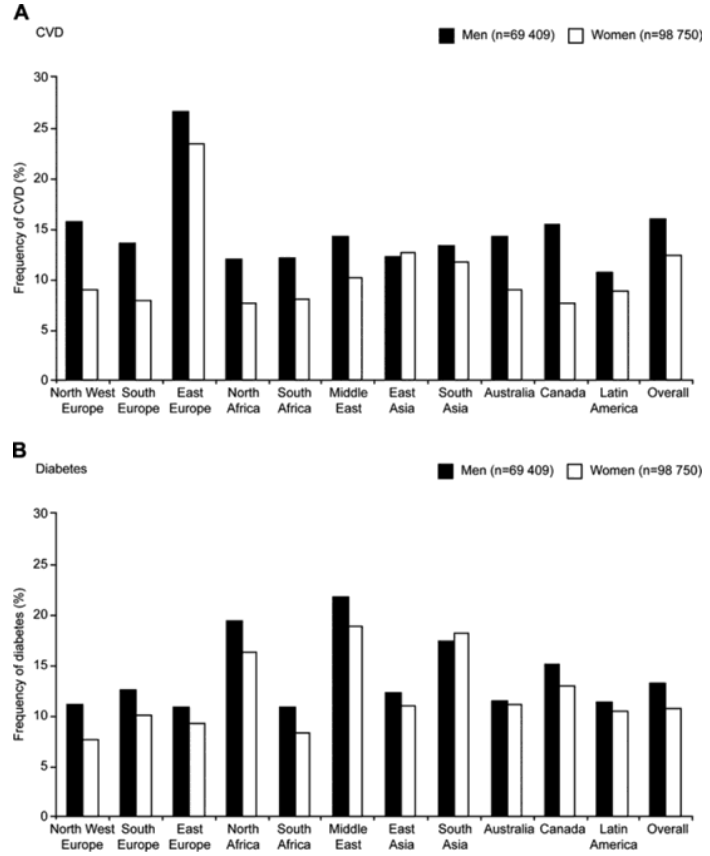

Figure 1. Age-standardized frequency of Agrdigkascillat2 (2013) diseases and diabetes mellitus by gender within

the different regions of the world (Balkau et al., 2007)

Due to the large amount of research in the past decades, the set of symptoms - collo- cating with insulin resistance/glucose intolerance, dyslipidemia, and hypertonia - called X syndrome and described by Reaven in 1988, has been broadened by several new elements.

In the possession of the newest scientific results, the significant international scientific associations, like the WHO (1998), the American NCEP ${ }^{7}-$ ATP-III (Adult Treatment Pan- el-III, 2001), and the IDF $^{8}$ (2005) have repeatedly modified the criteria system of metabolic syndrome:

- Primary conditions have been changed (e.g. abdominal obesity was not an indispens- able condition in 2001;

- Certain limit values have been tightened (e.g. in relations with high blood-pressure, or blood lipid-level);

- A set of symptoms has been linked to other pathographies (e.g. sleeping apnoe syn- drome, polycystic ovarian 
syndrome, etc.) (Nádházy et al., 2008)

These slightly differing criteria systems were in use until 2009, when a unified attitude was accomplished at the Conference of Harmonization.

National Cholesterol Education Program

8 International Diabetes Federation

PUSZTAI Ágnes, SCHANDL László: Changes in terms of metabolic syndrome, its occurrence...

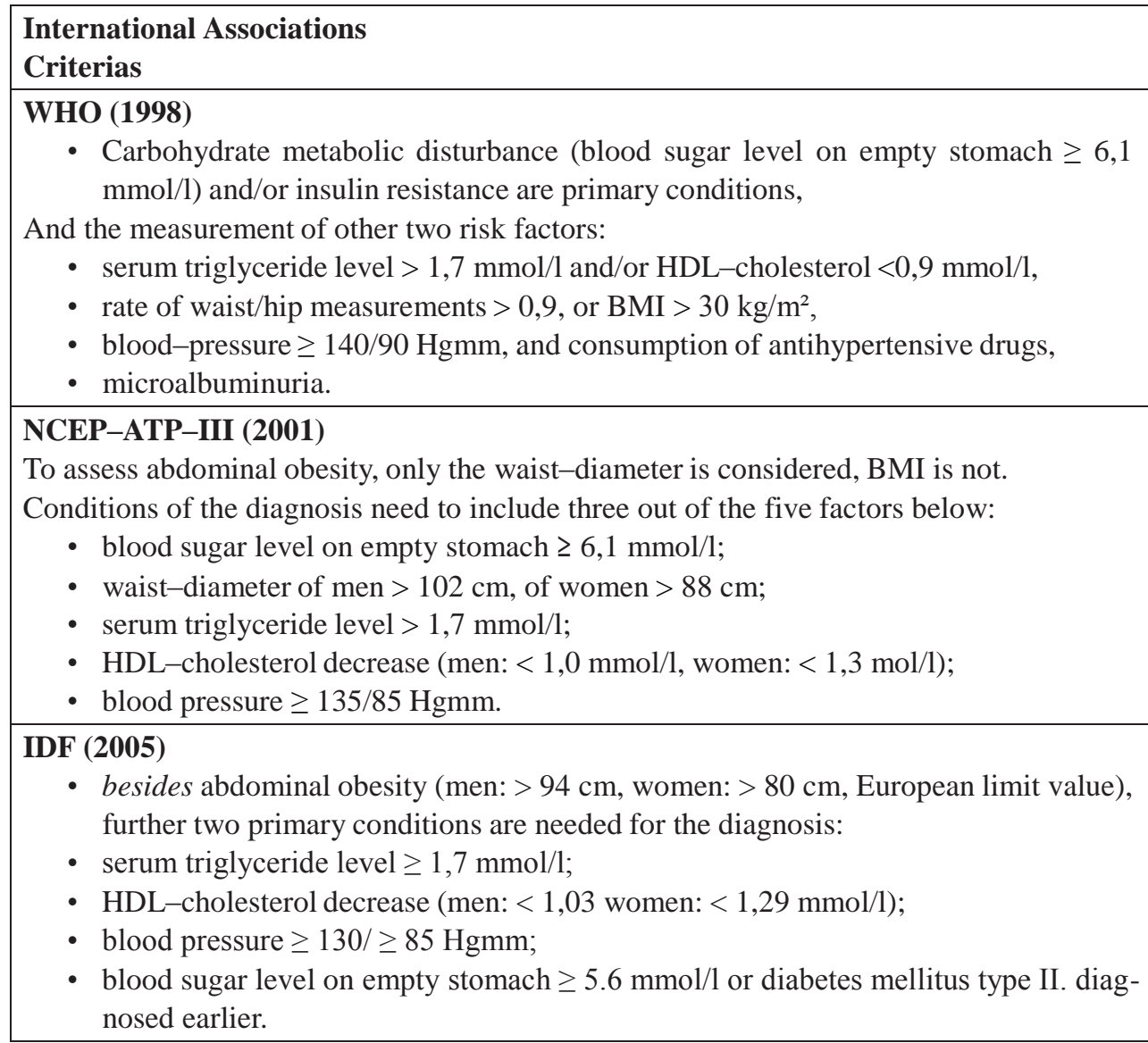

Table 2. Shift of stress in defining metabolic syndrome between 1998-2005

In 1988, the WHO defined carbohydrate metabolic disorder (blood sugar level on empty stomach $\geq 6,1 \mathrm{mmol} / \mathrm{l}$ ) and/or insulin resistance as primary conditions to diagnose the syn- drome. The definition formed by NCEP-ATP-III in 2001 is the most extensively applied criteria system. It considered only the waist diameter to evaluate abdominal obesity, but not the BMI.

The criteria system defined by IDF in 2005 already included abdominal obesity as a pri- mary condition. This was the first instance that attention was called to the ethnic diversity of increased risk factor rating by the waist diameter. (Zimmet, Alberti, 2006)

In 2009, at the "Conference of Harmonization" a unified position and criteria system was set up by reconciling the results of f $_{2}$ rmener 2013 search (Alberti et al., 2009) and the following consensus was reached 345

- Metabolic syndrome is a sum of risk factors relating to cardiovascular diseases and di- abetes mellitus type II. These factors can be the following: hyperglycemia, high blood pressure, elevated triglyceride level, low HDL cholesterol level, or obesity (especially abdominal obesity);

PUSZTAI Ágnes, SCHANDL László: Changes in terms of metabolic syndrome, its occurrence..

- Risk factors occur more often together than separately (and the reason is often unex- plained). The syndrome is the sum or the combination of these risk factors;

- The syndrome is widespread and shows growing frequency worldwide. This tendency is closely bound up with rising obesity and inactive lifestyle;

- An agreement has been reached that abdominal obesity is not a compulsory condition, but the measurement of waist-diameter continues to be a useful pre-screening tool. Three existing terms out of the five risk factors supports the diagnosis of metabolic syndrome. The international associations have accepted the same limit value, 
except the value of the waist diameter, for which different limit values are suggested per eth- nicity and global region;

- The most extensively accepted risk factors of the metabolic syndrome include the fol- lowing: atherogenic dyslipidemia, high blood pressure, and hyperglycemia. Athero- genic dyslipidemia is the sum of lipoprotein disorders, such as the elevated level of serum triglyceride and apolipoprotein-B, increased LDL ${ }^{9}$ level and decreased HDL level. Most of the patients suffering from metabolic syndrome also have abdominal fatness and insulin resistance;

- Metabolic syndrome is not an absolute risk indicator since it does not include many of the absolute risk terms like age, gender, smoking, positive family anamnesis, phys- ical inactivity, LDL and total level of cholesterol. These terms altogether with the risk factors of metabolic syndrome are referred to as cardiometabolic risk. However, metabolic syndrome in itself without the other risk factors can double the instances of cardiovascular diseases and fivefold the instances of diabetes mellitus type II in 5-10 years. (Alberti et al., 2009)

\section{The term cardiometabolic risk}

The systems (Faringham, SCORE) that are created to estimate cardiovascular risk and based on the specifications of both the cardiovascular risk deriving from the components of the metabolic syndrome and the traditional risk factors - like age, gender, smoking, blood pres- sure, total cholesterol level — often underestimate the cardiovascular risk of individuals with medium risk-level, especially of women. (Benczúr, 2008) Therefore it is accepted that all risk factors need to be considered, meaning that besides the criteria of the metabolic syndrome the importance of other cardiovascular (absolute) risk factors - like age, gender, smoking, positive family anamnesis, physical inactivity, LDL and total cholesterol level - is indisputable. All these together need to be considered to assess the prognosis. These changes of approach led to the creation of the term "cardiometabolic syndrome". (Després, Lemieux,

2006) Accordingly, an individual having at least three of the "traditional" risk factors (smok- ing, abdominal obesity, hypertonia, hypercholesterolemia and/or high LDL-cholesterol and low HDL-cholesterol level) and at least one of the "residual" risk components can be con- sidered a person with high risk-level, even if the individual's SCORE value is less than 5\% (medium risk-level). (Farsang, 2012):

- cardiometabolic disorder (increased blood sugar level on empty stomach, impaired fasting glucose - IFG or impaired glucose tolerance - IGT);

PUSZTAI Ágnes, SCHANDL László: Changes in terms of metabolic syndrome, its occurrence...

- increased blood sugar level on empty stomach, postprandial triglyceride level;

- high uric acid level;

- obstructive sleeping apnoe;

- chronic obstructive pulmonary disorders;

- erectile dysfunction;

- insulin resistance;

- indicators of inflammation and prothrombotic state;

- presence of atherogenic lipoproteins.

In accordance with the agreement of the Harmonization Conference, the Hungarian crite- ria system to diagnose metabolic syndrome was defined by the principles of the $5^{\text {th }}$ Hungarian Cardiovascular Consensus Conference:

- abdominal diameter $>102 \mathrm{~cm}$ for men, $>88 \mathrm{~cm}$ for women;

- serum triglyceride level $>1,7 \mathrm{mmol} / \mathrm{l}$, or being under treatment;

- a HDL-cholesterol $<1,0 \mathrm{mmol} / \mathrm{l}$ for men, < 1,3 mol/l for women;

- or being under treatment;

- blood sugar level on empty stomach > 5,6 mmol/l or diabetes mellitus type II. Identified;

- blood pressure $\geq 130 / 85 \mathrm{Hgmm}$.

9 tphrensitylipoprotein there is no difference among the importance of each criteria. (Szollár et al., 2012) AARMS (12) 2 (2013)

\section{Pathogenesis of metabolic syndrome}

The importance of many pathogenic factors is emphasized in the development of the meta- bolic syndrome. According to a point of view, abdominal (visceral) obesity is the deciding factor. (Fabbrini et al., 2010) The increase of the abdominal adipose tissue is significant from not only the energetics aspects, but it is also the "mobilizing" organ of general endocrine, when the adipose tissue outflow of several hormone, inflammatory and thrombogen medi- ators produces the low-level inflammation - the essence of the syndrome - and all of its consequences. (Szollár, 2010)

\section{Insulin resistance}


In 1939, Hinsworth and Kerr experienced a smaller effect in one third of the cases when insu- lin was administered to their patients with diabetes, meaning that these patients had reduced insulin sensitivity. Insulin resistance can be defined as a state of having smaller than regular biological response to a regular dose of insulin. Insulin takes its biological effect primarily in the adipose tissue, the muscle tissue, and the liver. Therefore insulin resistance can develop in these organs and tissues. According to the assumptions, insulin resistance is developed first in the adipose tissue; insulin resistance of the muscle tissue and the liver is a consequence. (Urich, 2005)

By increasing insulin resistance, vasoactive substances, hormones, and cytokines pro- duced by the adipocytes facilitate the development of $\mathrm{VLDL}^{10}$ in the liver, therefore it boosts the accumulation of lipoproteins rich in triglycerides. In addition, the decomposition of li-

PUSZTAI Ágnes, SCHANDL László: Changes in terms of metabolic syndrome, its occurrence...

poproteins rich in triglycerides decreases due to the reduced activity of lipoprotein lipase. (Harangi, Paragh, 2008) The outflow of adipose acid from the fat cells in the insulin-resistant adipose tissue is increased by the decreasing lipogenesis and the boosting lipolysis. Although the primary reason of insulin resistance of the skeletal muscle and the liver is the higher concentration of FFA ${ }^{11}$; the hormones produced by the adipose tissue, the adipocytes (leptin, resistin, adiponectin), and the inflammatory mediators (e. g. TNF- $\alpha, \mathrm{IL}-6$ ) also significantly impact the insulin sensitivity of the liver and the muscle tissues.

Leptin is produced in larger amounts in the subcutaneous adipose tissue and it regulates the energy homeostasis. Thanks to the leptin, the plasma's FFA-level is reduced, that protects the cells from lipotoxicity. In case of obesity, the plasma's FFA-level grows, that refers to leptin resistance. The increased leptin-level correlates with the visceral obesity and the insu- lin resistance. The growth of resistin, IL-6-, and TNF- $\alpha-$ level boosts the insulin resistance. Adiponectin - a favorable anti-inflammatory hormone - improves the oxidation of adi- pose acid, reduces the level of triglyceride, and boosts the glucose metabolism by increased insulin sensitivity. (Urich, 2005)

\section{The occurrence of metabolic syndrome and the significance of car- diometabolic risk in the military}

The number of servicemen meeting the criteria of metabolic syndrome in NATO and the NATO armies has grown parallel to obesity. (Ceppa et al., 2008), (Costa et al., 2011) The middle-aged force is affected mainly, similarily to the civilian population of countries with advanced industry where the frequency of metabolic syndrome was already 20 $30 \%$ in the

90's. Kaffka and his team (Kaffka et al., 1999) researched a German flight navigator crew of almost 10,000 members to evaluate the risk of the occurrence of metabolic syndrome. They defined the frequency of obesity, hypertonia, and dyslipidemia as individual risk factors, or their combination. The military and the civilian control group of the flight navigator crew were evaluated to be in good condition from the aspect of metabolic syndrome occurrence and no significant difference was found between their states of health. They found this to be the result of regular and a highlevel of medical check-ups.

According to a French study from 2008, that examined the anthropometric data and lab results of servicemen aged 20-58 ( $\mathrm{n}=2045)$, it was found that those meeting the criterias of metabolic syndrome had higher BMI and waist diameter (BMI average $29.5+-3.4 \mathrm{~kg} / \mathrm{m}^{2}$, waist diameter average $103+-10 \mathrm{~cm}$ ). Individuals with no risk of metabolic syndrome had average BMI of $24.8+-2.9 \mathrm{~kg} / \mathrm{m}^{2}$, and average waist diameter of $88+-9 \mathrm{~cm}$ ). (Ceppa et al., 2008)

A study carried out among American trainees presented results that the occurrence of $30 \mathrm{~kg} / \mathrm{m}^{2} \mathrm{BMI}$ was around $14 \%$ and the frequency of smoking was around 30\%. Comparing these results to previous data, it was found that the trainees are less fit physically and have excess weight, which derives from obesity. (Pasiakos et al., 2012)

PUSZTAI Ágnes, SCHANDL László: Changes in terms of metabolic syndrome, its occurrence...

10 very low-density lipoprotein

\section{Cardiometabolic risk in the military forces of the Hungarian Defense Forces}

The cardiovascular risk factors, like smoking, physical inactivity, and BMI level in the rep- resentative sample of the contractual and the professional forces of the Hungarian Defense Forces are as follow (the control group included Hungarian civilians older than 15):

\begin{tabular}{|l|c|c|c|c|c|c|}
\hline & \multicolumn{2}{|c|}{ Never smoked } & \multicolumn{2}{c|}{ Currently smoking } & \multicolumn{2}{c|}{ Abandoned smoking } \\
\hline & Men & Women & Men & Women & Men & Women \\
\hline Civilians (n=1179) & 35 & 59.8 & 36.9 & 24.6 & 24.5 & 12.4 \\
\hline
\end{tabular}




\begin{tabular}{|l|c|c|c|c|c|c|}
\hline $\begin{array}{l}\text { Servicemen } \\
\mathrm{n}=4247)\end{array}$ & 43.9 & 51 & 33.9 & 31 & 22.2 & 18 \\
\hline
\end{tabular}

Table 3. Frequency of smoking (\%) by gender of civilians older than 15 (ELEF, 2009*) and servicemen older than 18 (source: medical check-ups in $)^{12}$

The table presents that the rate of non-smokers is almost two-times higher among wom- en than men. The rate of female smokers is higher among servicemen than civilians.

Physical activity was evaluated through questionnaires. According to the answers, ser- vicemen are more active physically than the Hungarian civilian population. A quarter of the servicemen and half of the civilians do not do any kind of sport activities. 25\% physical in- activity was measured among servicemen - meaning that a quarter of the soldiers do not do sports or exercise regularly — is very high compared to the physical expectations (Figure 2.).

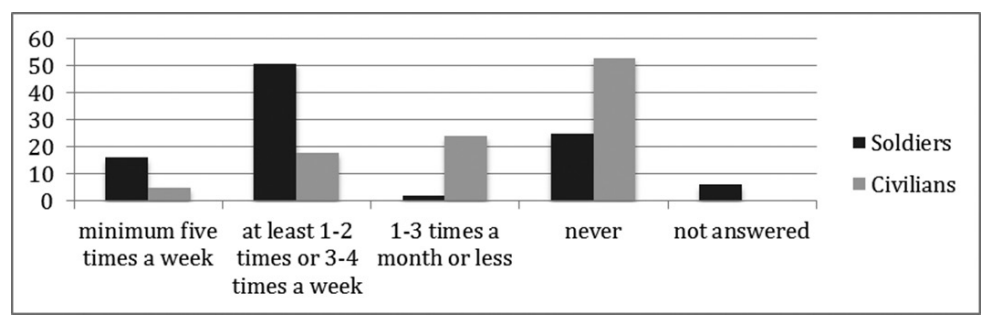

Figure 2. Indicators of physical activity (regular exercise and sport) among individuals older than 30 in the Hungarian Defense Force in 2011 and individuals older than 15 in the Hungarian population in 2010* (servicemen and civilians) (Eurobarometer, 2010)

Obesity occurs a lot among foreign and national military forces. Abdominal obesity in the staff of the Hungarian Defense Forces often goes together with high blood pressure - the most frequent health issue requiring medicinal therapy, - hyperglycemia, and dyslipidemia (Figure 3.). Women in the military have the most satisfactory BMI, better than civilian wom- en have. In the military sample of ages older than 30, there are no slim men and only a few women, which means that body weight increases by age. Most of the men with excess weight belong to the military, however on the bases of BMI it is impossible to differentiate between greater weight of muscle and true obesity. Civilian men and women are more overweight.

PUSZTAI Ágnes, SCHANDL László: Changes in terms of metabolic syndrome, its occurrence...

The information value of the data collected is limited because active servicemen at fit-towork age are compared to civilians, which has a significant rate of individuals older than 65 .

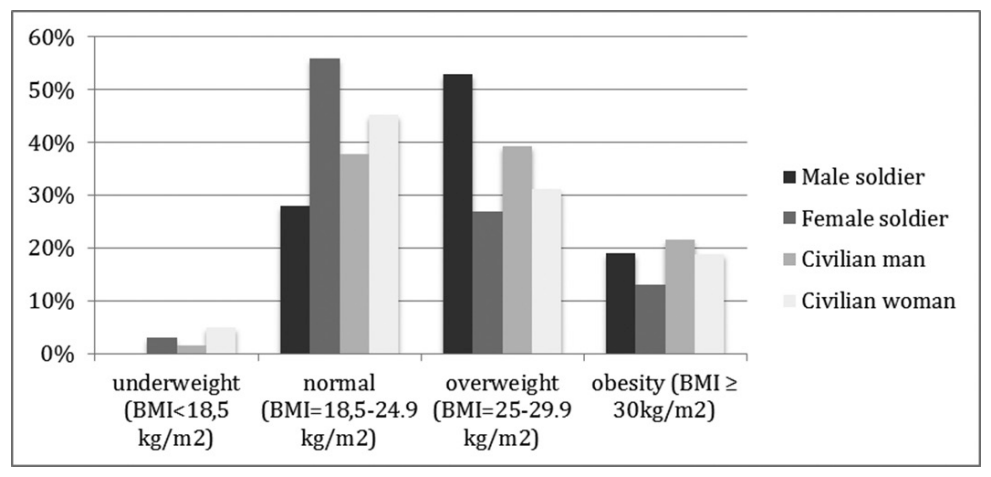

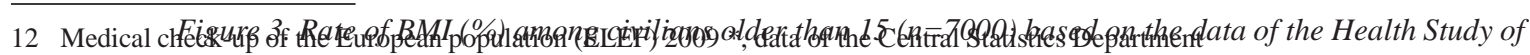
the European Population from 2009 and among servicemen older than $30(n=4247)$ in the Hungarian

\section{Summary}

The first step of cardiovascular illness prevention is to define the risk status, for which using the SCORE table considering the samples of the European population - is still recommend- ed. (European Guidelines, 2012) The table presents the possibilities of fatal cardiovascular disorders expected in the next 10 years by age, gender, systolic blood pressure, smoking, and serum cholesterol level. The relative exposure based on the same age and parameters can be defined individually. The prevention team includes the family doctor, who filters the individ- uals with exposure, prepares risk assessment, and takes care of further treatment. Following the complementary non-invasive cardiology 
examinations, the cardiologist sets the medic- inal therapy and prepares intervention if necessary. Prevention needs to include communi- cation towards the population and education. Hungary is one the countries with high-risk, therefore the table in accordance (Vértes, 2013) is recommended to be used.

Based on the cardiometabolic risk factors, servicemen are more exposed despite the pos- itive physical activity indicators. To reduce this risk, primary and secondary prevention is a fundamental task in military health-care as well in order to maintain capable forces.

\section{References}

ALBERTI, K. G., ECKEL, R. H., GRUNDY, S. M., ZIMMET, P. Z., CLEEMAN, J. I., DONATO, K. A., FRUCHART, J. C., JAMES, W. P., LORIA, C. M., SMITH, S. C. Jr, (2009): Harmonizing the metabolic syndrome. Circulation, Vol. 120 Issue 16, pp. 1640-5. https://doi.org/10.1161/CIRCULATIONAHA.109.192644

BALKAU, B., DEANFIELD, J. E., DESPRÉS, J. P., BASSAND, J. P., FOX, K. A. A., SMITH, S. C., BARTER, P. Jr., TAN, C. E., van GAAL, L., WITTCHEN, H. U., MASSIEN, C., HAFFNER, S. M. (2007): International Day for the Evaluation of Abdominal Obesity (IDEA): A Study of Waist Circumference. Circulation, Vol. 116, pp. 1942-1951 doi: 10.1161/ CIRCULATION AHA.106.676379

PUSZTAI Ágnes, SCHANDL László: Changes in terms of metabolic syndrome, its occurrence..

BENCZÚR B. (2008): Előnyösebbek-e az artériás stiffness paraméterek a konvencionális rizikófaktoroknál (SCORE) a cardiovascularis rizikó becslésében? Magyar Artériás Stiffness Társaság IV. Nemzetközi Artériás Stiffness Szimpóziuma, Budapest, Február 22-23.

CEPPA, F., MERENS, A., BURNAT, P., MAYAUDON, H., BAUDUCEAU, B. (2008): Military Community: A Privileged Site for Clinical Research: Epidemiological Study of Metabolic Syndrome Risk Factors in the Military Environment. Military Medicine, Vol. 173 Issue. 10, pp. 960-967. https://doi.org/10.7205/milmed.173.10.960

COSTA, F. F., MONTENEGRO, V. B., LOPES, T. J., COSTA, E. C. (2011): Combination of risk factors for metabolic syndrome in the military personnel of the Brazilian Navy. Arquivos Brasileiros de Cardiologia, Vol. 97 Issue 6, pp. 485-92., E-pub October 27. https://doi.org/ 10.1590/s0066-782x2011005000113

DESPRÉS, J. P., LEMIEUX, I. (2006): Abdominal obesity and metabolic syndrome. Nature, Vol. 444, pp. 881-887. https://doi.org/10.1038/nature05488

EUROBAROMETER (2010): Sport and Physical Activity, http://ec.europa.eu/sport/library/documents/d/ebs_334_en.pdf (downloaded: 2103 2013)

EUROPEAN GUIDELINES on cardiovascular disease prevention in clinical practice (2012): The Fifth Joint Task Force of the European Society of Cardiology and Other Societies on Cardiovascular Disease Prevention in Clinical Practice (constituted by representatives of nine societies and by invited experts). European Heart Journal, Vol. 33, pp. 1635-1701 https://doi.org/10.1093/eurheartj/ehs092

FABBRINI, E., SULLIVAN, S., KLEIN, S. (2010): Obesity and non-alcoholic fatty liver disease: biochemical, metabolic and clinical implications. Hepatology, Vol. 51, pp. 679-689. FARSANG Cs.

(2010): A kardiometabolikus kockázat. Metabolizmus, Február Vol. VIII, Issue 1, pp. 4-9 https://doi.org/10.1002/hep.23280

HARANGI M., PARAGH Gy. (2008): Elhízás, mint kockázati tényező. Metabolizmus, 6. évfolyam 4. szám

KAFFKA, K. G., MAYA-PELZER, P., ALEXANDER, A., DEUBER, H. J. (1999): Prevalence of the metabolic syndrome in military and civilian flying personnel. Aviation, Space, and Environmental Medicine, Vol. 70 Issue 12, pp. $1223-6$

NÁDHÁZY Z., FORSTER T., HÖGYE M. (2008): Metabolikus szindróma: visceralis obesitas, atherogen dyslipidaemia, diabetes mellitus, hipertónia és a kardiovaszkuláris rizikó. Metabolizmus, 6. évfolyam 3. szám

PASIAKOS, S. M., KARL, J. P., LUTZ, L. J., MURPHY, N. E., MARGOLIS, L. M., ROOD, J. C., CABLE, S. J., WILLIAMS K. W., YOUNG, A. J., McCLUNG, J. P. (2012): Cardiometabolic Risk in US Army Recruits and the Effects of Basic Combat Training. PLoS ONE, Vol. 7 Issue 2, https://doi.org/10.1371/journal.pone.0031222 http://www.plosone.org/article/info\%3Adoi\%2F10.1371\%2Fjournal. pone.0031222 (downloaded: 1703 2013)

SZOLLÁR L. (2010): A zsírmáj és a globális kardiometabolikus kockázata. Orvosi Hetilap, Vol. 151, pp. 1946-50. https://doi.org/10.1556/OH.2010.29003

SZOLLÁR L., PADOS Gy., BALOGH S., BEDROS J. R., CSIBA L., CZURIGA I., De CHÂTEL R., FARKAS K., FARSANG Cs., GRUBER N., HALMY L. (2012): Összefoglalás az V. Magyar Kardiovaszkuláris Konferencia ajánlásairól. Az V. Magyar Kardiovaszkuláris Konszenzus Konferencia Ajánlása, 2011. Metabolizmus, Vol. 10, Supplementum A/2012

URICH E. (2005): Inzulinrezisztencia — célkeresztben a zsírszövet, In. Orvosi Hetilap, Vol. 146, pp. 2199-2207

VÉRTES A. (2013): Kardiovaszkuláris prevenció. Metabolizmus, 11. évfolyam 1. szám

WHO (2009): European Health-for-All database, Copenhagen: WHO Regional Office for Europe

ZIMMET, P., ALBERTI, K. G. (2006): The IDF Definition: why we need a global consensus. Diabetes Voice, Vol. 51 Special Issue, pp. 11-14. 